4. Блащак Б.Я. Фінансовий потенціал у структурі потенціалу підприємства. Вчені записки ТНУ імені В. I. Вернадського. Серія: Економіка і управління. 2019. Том 30 (69). №3. С. 74-78.

\title{
References:
}

1.Kulish G., Chepka V. The financial potential of the enterprise and its role in conditions of economic instability. Statistics of Ukraine. 2017. № 1. pp. 29-35.

2.Goncharenko M. Evolution of the essence of financial potential of development of territories. Theory and practice of public administration. 2013. Issue. 3. URL: http://nbuv.gov.ua/UJRN/Tpdu_2013_3_25 (access date 28.11.2020).

3.Kostevych O. Financial potential of light industry enterprises in Ukraine. Light industry. 2010. № 3. pp. 27-30.

4.Blaschak B. Financial potential in the structure of enterprise potential. Scientific notes of TNU named after VI Vernadsky. Series: Economics and Management. 2019. Volume 30 (69). №3. pp. 74-78.

Дата подання публікації 25.12.2020 p.

УДК 338.1:658.33

Ліпич Л.Г., д.е.н. , професор, Lipych Liubov, Doctor of Economic Sciences, Professor, https://orcid.org/0000-0002-9059-7271

Хілуха О.А., к.е.н.,доцент Khilukha Oksana, Candidate of Economic Sciences, Associate Professor https://orcid.org/0000-0002-12287171

Кушнір М.А., к.е.н., доцент

Kushnir Myroslava, Candidate of Economic Sciences, Associate Professor https://orcid.org/0000-0002-4441-4278

\section{ІНФОРМАЦІЙНЕ ЗАБЕЗПЕЧЕННЯ СТРАТЕГІЧНОГО ВИБОРУ}

\author{
Луиьький національний технічний університет \\ Львівський університет бізнесу та права \\ Украйнський католицький університет
}

\begin{abstract}
У статті зазначено, що з точки зору інформаційної підтримки стратегічного вибору, інформаційне забезпечення полягає у наданні інформаційних даних у встановленому законом порядку, у процесі якого на базі інформаційних систем та із застосуванням принципів, методів, способів, правил, схем та алгоритмів здійснюється пошук інформації, ії збір, обробка, нагромадження, зберігання, передача та використання у обсязі, достатньому для прийняття оптимальних рішень. Обгрунтовано форми інформаційної підтримки на всіх етапах стратегічного вибору із зазначенням конкретних інструментів.

Доведено, що 3 допомогою IT-систем можна реєструвати та обробляти обсяги даних, що генеруються у структурах підприємства. Доступ до інформації є визначальною умовою прийняття раціональних рішень щодо розвитку підприємства. Сукупність отриманої інформації - базою знань. Генеровані знання визначають спосіб поведінки підприємства. Довіра до інформації перетворюється на якість знань, а останні в точність стратегічних рішень.

Ключові слова: інформачійна підтримка, форми інформаџійної підтримки, IT-система, види інформації, етапи стратегічного вибору, теорій стратегічного вибору.
\end{abstract}

\section{INFORMATIVE PROVIDING OF STRATEGIC CHOICE}

\author{
East-European National University of Lesya Ukrainka (Lutsk) \\ East-European National University of Lesya Ukrainka (Lviv) \\ Ukrainian Catholic University (Lviv)
}

An important task of management is to create a system of information support. It allows you to collect and process internal and external information necessary to make informed strategic choices regarding the insurance of strategic development. 
The purpose of the article is to review modern approaches to defining the essence of the concept of information support and identification of the main aspects of the formation of an effective system of information support for the process of strategic choice of the enterprise.

The article states that in terms of information support of strategic choice, information support is to provide information in the manner prescribed by law, in the process of which on the basis of information systems and using principles, methods, techniques, rules, schemes and algorithms its collection, processing, accumulation, storage, transfer and use in an amount sufficient to make decisions optimal for the enterprise.

Forms of information support at all stages of strategic choice with indication of specific tools are substantiated. The model of the strategic selection process shows that information support allows you to quickly import data related to the detection of problems coming from different sources.

It has been proven that with the help of IT systems that support strategic choice, it is possible to record and process large amounts of data generated in all functional structures of the enterprise. Access to hidden information, often difficult to access, is a determining condition for making rational decisions about enterprise development. The set of received information (both secondary and primary) is a knowledge base. The generated knowledge determines the behavior of the enterprise. Trust in information is transformed into the quality of knowledge, and the latter into the accuracy of strategic decisions, which is reflected in the achieved economic results of the enterprise.

Emphasis is placed on the fact that strategists should be provided with information systems focused on the perception and interpretation of weak signals. This is the information basis of the strategic selection process. By receiving information that reduces uncertainty, the manager has the opportunity to make rational decisions.

Key words: information support, forms of information support, IT system, types of information, stages of strategic choice, theories of strategic choice.

Постановка проблеми у загальному вигляді i ï̈ зв'язок 3 важливими науковими та практичними завданнями. Важливою умовою ефективної діяльності та розвитку підприємств у сучасних умовах господарювання є здатність оперативно реагувати на появу нових ринкових можливостей та використовувати свій конкурентний потенціал. В таких умовах ключового значення набуває стратегічний вибір підприємства. Для прийняття ефективних управлінських рішень необхідна система інформаційної підтримку процесу стратегічного вибору, яка своєчасно та адекватно характеризуватиме внутрішні процеси та ринкове середовище підприємства. Саме тому важливим завданням менеджменту є створення системи інформаційного забезпечення, яка дає змогу збирати і опрацьовувати внутрішню та зовнішню інформацію, необхідну для прийняття обгрунтованого стратегічного вибору щодо асекурації стратегічного розвитку.

Аналіз останніх досліджень, у яких започатковано вирішення проблеми. Проблемі інформаційного забезпечення процесу управління підприємства відведено чимало зарубіжних та вітчизняних наукових праць. Питанням сутності інформаційного забезпечення займалися вітчизняні вчені М.Я. Дем'яненко, Т.Г. Камінська, О.М. Хорін, Т.В. Грачов, С.В. Маркова. Серед зарубіжних вчених ватро відзначити: А. Томпсона, Р. Роджерса, К. Лорда, М. Джобса та інших. Проте на сьогодні багато питань з області інформаційної асекурації залишаються недостатньо вивченими, зокрема особливої уваги в умовах мінливості ринку потребує детального вивчення інформаційних аспектів процесу стратегічного вибору в контексті прийняття обгрунтованих рішень.

Цілі статті. Метою статті є огляд сучасних підходів щодо визначення сутності поняття інформаційне забезпечення та ідентифікація основних аспектів формування ефективної системи інформаційної підтримки процесу стратегічного вибору підприємства.

Виклад основного матеріалу з повним обгрунтуванням отриманих наукових результатів. Для сучасних підприємствах здійснення стратегічного вибору в динамічних, надзвичайно мінливих та невизначених умовах без використання інструментів, що імплементовані в інформаційні системи, які підтримують управління, є суттєво складним або навіть неможливим. Це стосується також методів та інструментів стратегічного аналізу, стратегічного планування, а також інших інструментів, що використовуються в управлінні та надають інформацію, необхідну для прийняття рішень 
на стратегічному рівні. 3 іншого боку, зростаюча невизначеність зовнішнього середовища змушує нас приймати “швидкі” рішення і, водночас, покладатися на досвід, знання та інтуїцію осіб, які їх приймають, без проведення тривалого, вичерпного аналізу в різних функціональних сферах підприємства. Це основна причина залучення ITсистем, що забезпечують стратегічний вибір, яке полягає у комплексному впровадженні та використанні різних IT-систем управління, що мають можливості створення та використання даних у реальному та історичному часі [1]. Ці системи повинні бути оснащені інструментами формування звітів, моделями прогнозування майбутніх подій, інструментами для виявлення певних закономірностей, ідентифікації змінних та взаємозв'язків зовнішнього середовища та інституцій підприємств. Вони мають містити сучасні технологічні рішення, додатки та мобільні пристрої, що дозволяють отримувати різні дані, котрі інтерпретуються та постійно аналізуються відповідними організаційними підрозділами підприємства. Використання IT-систем, що підтримують управління, зменшує ризик, що супроводжує реалізацію процесу прийняття стратегічних рішень, шляхом його раціоналізації. Інформація, що надається ІТ-системами у формі доповідних записок та звітів i використовується для прогнозування майбутнього підприємства, опосередковано впливає на ефективність економічної діяльності як одного 3 ключових чинників його успіху.

Досліджуючи інформаційне забезпечення стратегічного управління, доцільно акцентувати увагу на процесі управління. Цей процес вимагає низки заходів, спрямованих на з'ясування поточної ситуації. У наукових дослідженнях у сфері економіки та управління $є$ різні підходи до визначення сутності інформаційного забезпечення. Більшість науковців під інформаційним забезпеченням пропонує розуміти сукупність інформації у комплексі зі способами іï організації (пошук, нагромадження, оброблення, зберігання і використання) або інформаційними системами, і лише деякі як інформаційну базу даних або як елемент інформаційних систем. Такий підхід можна вважати техніко-технологічним (інформаційно-технологічним). Іншим підходом $€$ управлінський, із позицій якого інформаційне забезпечення розглядається науковцями в контексті обслуговування управління та надання необхідної для управлінських рішень інформації або як механізм управління. В окремих випадках застосовується технікотехнологічний і управлінський підходи разом [2]. 3 точки зору інформаційної підтримки стратегічного вибору, інформаційне забезпечення полягає у наданні інформаційних даних (наприклад, цифрових, інформативних, аналітичних, законодавчих, нормативних, щодо форм документів тощо) у встановленому законом порядку, у процесі якого на базі інформаційних систем та із застосуванням принципів, методів, способів, правил, схем та алгоритмів здійснюється пошук інформації, іiі збір, обробка, накопичення, зберігання, передача та використання у обсязі, достатньому для прийняття рішень оптимальних для підприємства.

Інформаційна підтримка необхідна на всіх етапах стратегічного вибору (табл. 1). Через його особливості вимоги до інформації мають суттєво інший характер, про що свідчить обсяг матеріалу, що обробляється. Модель процесу стратегічного вибору засвідчує, що інформаційна підтримка дозволяє швидко імпортувати дані пов'язані з виявленням проблеми, що надходять із різних джерел (перша фаза процесу) [3]. Слід додати, що без інтерпретації отриманих даних неможливо прийняти правильні стратегічні рішення. Представлені дані повинні бути актуальними та мати відповідний рівень деталізації, а також легко доступними для уповноважених користувачів. Інформація, що надається на наступних етапах процесу, повинна допомогти визначити суть проблеми та відображатися конкретними параметрами (друга стадія процесу). Інформаційна підтримка також застосовується для визначення варіантів рішень (третя фаза процесу), пропонуючи набір альтернатив та оцінюючи обрані варіанти з точки зору задоволення очікувань тих, хто приймає рішення (четверта стадія процесу). 
Таблиця 1

Діапазон інформаційної підтримки на етапах стратегічного вибору

\begin{tabular}{|c|c|c|}
\hline Етап процесу стратегічного вибору & Сутність етапу & Форма підтримки \\
\hline Ідентифікація проблеми & $\begin{array}{c}\text { Сприйняття сигналів та реєстрація } \\
\text { проблеми }\end{array}$ & Надання інформації \\
\hline $\begin{array}{l}\text { Ідентифікація зовнішніх та } \\
\text { внутрішніх чинників впливу }\end{array}$ & Визначення стратегічних проблем & Надання інформації \\
\hline $\begin{array}{c}\text { Формулювання стратегічних } \\
\text { варіантів }\end{array}$ & $\begin{array}{c}\text { Визначення можливих шляхів } \\
\text { провадження - ідентифікація } \\
\text { варіантів вирішення стратегічних } \\
\text { проблем } \\
\end{array}$ & Пропонування рішень \\
\hline $\begin{array}{c}\text { Стратегічний вибір - прийняття } \\
\text { рішення }\end{array}$ & $\begin{array}{c}\text { Визначення остаточного варіанту та } \\
\text { його оцінка } 3 \text { точки зору очікувань } \\
\text { тих, хто приймає рішення }\end{array}$ & Надання інформації \\
\hline
\end{tabular}

Джерело: авторське напрацювання на основі [3,4].

Інформація, необхідна для здійснення стратегічного вибору повинна бути об’єктивною, достовірною та актуальною, а також сприяти прийняттю оптимальних стратегічних рішень. У той же час необхідно зазначити, що стратеги ніколи не можуть розглянути всі можливі варіанти. Пояснюється це тим, що їх безліч. Тому важко визначити “найкращий”. Це пов'язано з обсягом інформації та знань про дану стратегічну проблему. Висока якість є результатом обробки великого обсягу інформації, що використовується в процесі прийняття рішень. Чим більший обсяг інформації доступний особі, яка приймає рішення, тим більший шанс створити або вибрати кращий варіант. Види інформації, що використовується у стратегічному управлінні та в процесі стратегічного вибору, відповідно до загальновизнаних науковцями критеріїв, представлені в табл. 2.

Таблиця 2.

Характеристика інформації, що використовується підприємствами в процесі стратегічного вибору

\begin{tabular}{|c|c|}
\hline Ознаки інформації & Характеристика \\
\hline Діапазон & Дуже широкий, охоплює всю систему управління підприємством. \\
\hline Значення для підприємства & Найважливіша. \\
\hline Рівень агрегації & $\begin{array}{c}\text { Високий, інформація, подається у формі звітів та аналітичних } \\
\text { результатів, використання значної кількості показників та } \\
\text { математичних формул. }\end{array}$ \\
\hline Часовий горизонт & $\begin{array}{l}\text { В основному стосується майбутнього, домінують довгострокові } \\
\text { прогнози та моделі, використовується аналіз ретроспективи. }\end{array}$ \\
\hline Форма сигналів & $\begin{array}{c}\text { Інформація є результатом аналізу складних причинно-наслідкових } \\
\text { зв'язків, велике значення мають слабкі сигнали. }\end{array}$ \\
\hline Зв’язок із сучасністю & $\begin{array}{c}\text { Мінімальний, переважає прогностична інформація, діагностична } \\
\text { інформація має незначний вплив. }\end{array}$ \\
\hline Точність & Узагальнена, приблизна, агрегована \\
\hline Джерела & $\begin{array}{c}\text { Переважно зовнішні, пов'язані з близьким та віддаленим оточенням, } \epsilon \\
\text { також внутрішні. }\end{array}$ \\
\hline Спосіб представлення & Кількісна та якісна, візуалізація інформації. \\
\hline Рівень структурування & Незначний, низький рівень автоматизації процедур прийняття рішень. \\
\hline Частота & $\begin{array}{c}\text { Періодичні звіти, щомісячні та квартальні, часто у відповідь на зміни } \\
\text { на ринку }\end{array}$ \\
\hline
\end{tabular}

Джерело: авторське напраџювання на основі [5,6].

Стратегічний вибір менше стосується добре структурованих проблем (кількісно виражених, конкретних), де можна використати математичні моделі. Слабо структуровані (якісні, кількісно невизначені) $є$ основним викликом у стратегічному управлінні, оскільки вони не піддаються формалізації. Варто підкреслити, що чим вища складність проблеми, тим більше знань та ресурсів (фінансових, людських, технічних тощо) потрібно для iї вирішення. Чим вищий рівень управління та нижчий рівень структурування проблеми, тим більша необхідність ії підтримки сучасними 
інформаційними системами. 3 допомогою IT-систем, що підтримують управління, можна реєструвати та обробляти величезні обсяги даних, що генеруються у всіх функціональних структурах підприємства. Доступ до прихованої інформації, часто важкодоступної, є визначальною умовою прийняття раціональних рішень щодо розвитку підприємства. Сукупність отриманої інформації (як вторинної, так і первинної) є базою знань (табл. 3). Генеровані знання визначають спосіб поведінки підприємства. Довіра до інформації перетворюється на якість знань, а останні в точність стратегічних рішень, що відображається на досягнутих економічних результатах підприємства.

Таблиця 3.

Приклади стратегічного вибору та інформації, що необхідна для його прийняття

\begin{tabular}{|c|c|}
\hline Стратегічний вибір & Необхідна інформація \\
\hline $\begin{array}{l}\text { Розробка конструкції нового } \\
\text { продукту }\end{array}$ & $\begin{array}{c}\text { Вимоги замовника, функціональність, кількість варіантів, операційні } \\
\text { витрати, технічні та експлуатаційні параметри, термін служби. }\end{array}$ \\
\hline Вихід на ринок з новим продуктом & $\begin{array}{c}\text { Ринкова, про продукцію конкурентів, вимоги споживачів, ціни продажу, } \\
\text { операційні витрати, функціональні можливості, різноманітність варіантів, } \\
\text { обслуговування, дистрибуційна мережа. }\end{array}$ \\
\hline $\begin{array}{c}\text { Вихід на новий ринок із наявним } \\
\text { продуктом }\end{array}$ & $\begin{array}{c}\text { Ринкова, вимоги споживачів, дистрибуційна мережа, продукція } \\
\text { конкурентів, ціна. }\end{array}$ \\
\hline Придбання нової виробничої лінії & $\begin{array}{c}\text { Ефективність (продуктивність) лінії, витрати на монтаж гнучкість, } \\
\text { взаємозамінність операцій, експлуатаційні витрати, час технологічних } \\
\text { операцій, тривалість заміни. }\end{array}$ \\
\hline $\begin{array}{c}\text { Впровадження нової виробничої } \\
\text { системи }\end{array}$ & $\begin{array}{c}\text { Маршрути руху продукції та робітників, характеристики робочих місць, } \\
\text { план виробництва, характеристики системи обслуговування, } \\
\text { функціональність }\end{array}$ \\
\hline Будівництво логістичного центру & $\begin{array}{c}\text { Номенклатура, асортимент та обсяг запасів, коефіцієнт оборотності } \\
\text { запасів, мінімальні обсяги запасів, розміри партій замовлення, частота } \\
\text { видачі продукції, прогнози потреби в продукції, що зберігається в центрі. }\end{array}$ \\
\hline
\end{tabular}

Для інформаційного забезпечення процесів управління використовуються різні набори інструментів, що дозволяють розширити обсяг доступної інформації та запропонованих варіантів рішення. Очевидно також, що не існує єдиного ITінструменту, який би відповідав усім стратегічним викликам. У той час як на малих підприємствах складні інструменти можна замінити простими електронними таблицями - це класичний приклад інструментів аналізу даних, на багатогалузевих підприємствах зі складними та великими організаційними структурами, часто інтернаціоналізованими та розпорошеними, 3 філіями у багатьох країнах, виправдано та одночасно необхідно впроваджувати передові IT-системи, які використовуються як основні інструменти для підтримки процесів прийняття рішень, включаючи стратегічний вибір. $\mathcal{C}$ й інші причин для впровадження ІТ-систем, що підтримують управління. Необхідність в них може появитися, зокрема, при розширенні виробничої діяльності, співпраці з підприємством, що вже має таку систему, бажанні отримати інформацію більш високої якості, зміні стратегії, реорганізації, розширенні товарної пропозиції, виході на новий ринок, збільшенні зайнятості, або появі нових клієнтів чи іншій реакції на зміни в зовнішньому середовищі. IT-системи забезпечують ефективну підтримку та часткову автоматизацію процесу прийняття рішень, а також дозволяють використовувати безліч можливостей, властивих інформаційно-комунікаційним технологіям (IКT) (анг. ICT information and communication technology). В даний час підприємства використовують різноманітні стандартні IT-системи, що підтримують управління, до групи яких можна віднести насамперед системи ERP, BI, CRM та DMS. Завданням IT-систем, що підтримують стратегічний вибір, $є$ збір та обробка даних у формах, доступних для підприємства, та оприлюднення результатів відповідно до потреб стратегів. Жодна технологія не може замінити тих, хто приймає рішення, але вона повинна служити допоміжним інструментом, сприяти зниженню витрат, забезпечуючи співпрацю 3 різними зацікавленими сторонами, ідентифікуючи можливості та загрози, оптимізуючи споживання ресурсів або сприяти інтеграції знань через різні інформаційні потоки всередині підприємства та за його межами. 
Таблиця 4

Інформаційне забезпечення теорій стратегічного вибору підприємств

\begin{tabular}{|c|c|c|}
\hline Теорія & Сутність змін & Підтримка стратегічного вибору \\
\hline Теорія інформації & $\begin{array}{l}\text { Інформація, як матерія та енергія, } є \\
\text { об’єктом обміну між відносно } \\
\text { ізольованими системами та } \\
\text { зовнішнім середовищем. }\end{array}$ & $\begin{array}{l}\text { Інформація вважається } \\
\text { найважливішим компонентом будь- } \\
\text { якої системи (включаючи системи, } \\
\text { що підтримують стратегічний } \\
\text { вибір), оскільки вона упорядковує } \\
\text { та систематизує. }\end{array}$ \\
\hline Теорія інформаційних систем & $\begin{array}{l}\text { У кожній інформаційній системі є } \\
\text { елементи: відправник, передавач, } \\
\text { переданий сигнал, канал передачі, } \\
\text { прийнятий сигнал, приймач. }\end{array}$ & $\begin{array}{l}\text { Основним завданням інформаційної } \\
\text { системи у сфері стратегічного } \\
\text { управління є перетворення вхідної } \\
\text { інформації у вихідну. }\end{array}$ \\
\hline Інформаційна теорія підприємства & $\begin{array}{l}\text { Інформаційні структури та знання є } \\
\text { складовими підприємства. Їх } \\
\text { розвиток взаємопов'язаний } 3 \\
\text { удосконаленням структур обміну } \\
\text { інформацією }\end{array}$ & $\begin{array}{l}\text { Для підприємства важливий кожен } \\
\text { працівник (власники, менеджери, } \\
\text { службовці), оскільки вони } \\
\text { володіють певною інформацією, } \\
\text { яку використовують в процесі } \\
\text { стратегічного вибору. }\end{array}$ \\
\hline Інституційна теорія & $\begin{array}{l}\text { Змінне інституційне середовище } \\
\text { чинить тиск } \\
\text { на підприємства. Це змушує } \\
\text { підприємства приймати прийнятні, } \\
\text { а не раціональності рішення. }\end{array}$ & $\begin{array}{l}\text { Посилення інформаційної } \\
\text { підтримки стратегічного вибору } \\
\text { підприємств може означати відхід } \\
\text { від вимог інституційного } \\
\text { середовища, а отже негативних } \\
\text { реакції окремих зацікавлених } \\
\text { сторін. }\end{array}$ \\
\hline Теорія навчання & $\begin{array}{l}\text { Процес адаптації підприємства до } \\
\text { зовнішнього середовища базується } \\
\text { на здатності вчитися, навчатися та } \\
\text { перевчатись. }\end{array}$ & $\begin{array}{l}\text { Інформаційна підтримка } \\
\text { стратегічного вибору підприємств - } \\
\text { це постійний процес навчання.. }\end{array}$ \\
\hline Ресурсна теорія & $\begin{array}{l}\text { Унікальні ресурси та } \\
\text { компетентності (активи) } \\
\text { підприємства є основними } \\
\text { джерелами стійкої конкурентної } \\
\text { переваги }\end{array}$ & $\begin{array}{l}\text { Інформаційна підтримка } \\
\text { стратегічного вибору вбачається в } \\
\text { діяльності, що полягає в інтеграції } \\
\text { ресурсів, їх структуруванні та } \\
\text { реконфігурації для прийняття нових } \\
\text { рішень стратегічних проблем. }\end{array}$ \\
\hline Теорія динамічних здібностей & $\begin{array}{l}\text { В динамічному середовищі } \\
\text { специфічні динамічні здібності } \\
\text { призводять до отримання } \\
\text { конкурентних переваг, які пов'язані } \\
3 \text { його унікальністю. }\end{array}$ & $\begin{array}{l}\text { Динамічні здібності дозволяють } \\
\text { підприємству швидше та точніше } \\
\text { адаптуватися до будь-яких змін, які } \\
\text { враховуються при інформативній } \\
\text { підтримці стратегічного вибору. }\end{array}$ \\
\hline $\begin{array}{l}\text { Теорія динамічних аналітичних } \\
\text { здібностей }\end{array}$ & $\begin{array}{l}\text { Динамічні аналітичні можливості } \\
\text { визначаються як такі, що } \\
\text { допомагають особам, що } \\
\text { приймають рішення, створювати } \\
\text { цінність із доступних, великих, } \\
\text { інтелектуальних та якісних даних, } \\
\text { зібраних з однієї або декількох } \\
\text { інформаційних систем на } \\
\text { підприємстві. }\end{array}$ & $\begin{array}{l}\text { Підтримка процесу стратегічного } \\
\text { вибору на підприємстві полягає у } \\
\text { впровадженні та використанні } \\
\text { можливостей різних IT-систем та їх } \\
\text { постійному обслуговуванні. }\end{array}$ \\
\hline Агентська теорія & $\begin{array}{l}\text { Ця теорія використовується для } \\
\text { великої різноманітності агентських } \\
\text { відносин, в яких одна сторона } \\
\text { (принципал) делегує повноваження } \\
\text { і роботу іншій стороні (агенту), } \\
\text { який її виконує. }\end{array}$ & $\begin{array}{l}\text { Управління відносинами } \\
\text { принципал-агент по відношенню до } \\
\text { осіб, які беруть участь в } \\
\text { інформаційній підтримці процесу } \\
\text { стратегічного вибору. }\end{array}$ \\
\hline Мережева теорія & $\begin{array}{l}\text { Успіх підприємства досягається } \\
\text { завдяки управлінню внутрішньо } \\
\text { організаційними та між } \\
\text { організаційними зв'язками. }\end{array}$ & $\begin{array}{l}\text { У процесі інформаційного } \\
\text { забезпечення стратегічного вибору } \\
\text { можуть виникати різні внутрішні } \\
\text { зв'язки. }\end{array}$ \\
\hline Теорія зацікавлених сторін & $\begin{array}{l}\text { Ідентифікує осіб, які беруть участь } \\
\text { у процесі управління } \\
\text { підприємством та тих, хто } \\
\text { зацікавлений у його результатах. }\end{array}$ & $\begin{array}{l}\text { Зацікавлені сторони можуть } \\
\text { впливати на хід і якість процесу } \\
\text { стратегічного вибору. }\end{array}$ \\
\hline
\end{tabular}

Джерело: авторське напрацчювання на основі [7,8]. 
У 1985 р. М. Портер та В. Міллер у статті "Як інформація дає вам конкурентну" перевагу, вперше використали термін "інформаційна революція"[9], вказуючи на знання, необхідні для отримання конкурентних переваг, а це означає, що кожен менеджер потребує швидкої та достовірної інформації про підприємство та його оточення. 3 тих пір відбулося багато змін, спричинених високим рівнем динамічності зовнішнього середовища, технічним прогресом та зростаючими вимогами користувачів інформаційних систем управління. Підприємства збирають дедалі більше даних, які слід захистити, зберегти та проаналізувати. Щодня генерується величезна кількість інформації. Вона може бути невизначеною, неточною та швидко старіти. Тому підприємствам доводиться боротися із надлишком зібраних та збережених даних. Ця проблема виникає внаслідок перевантаження інформацією (ang. information overload), що є наслідком складності процесів, які відбуваються в зовнішньому середовищі. Це веде до зниження темпів розвитку підприємств. Сьогодні дані пов'язані в першу чергу 3 "великими обсягами" (Big Data), а системи підтримки прийняття рішень із сучасними інформаційними системами управління (Business Intelligence), що трактуються як багатовекторний інструмент, що дозволяє реалізовувати обрані стратегії.

Слід зазначити, що наявність IT-систем не забезпечує тривалої переваги, оскільки їх основні функції, такі як зберігання, обробка та передача даних, можуть стати загальнодоступними. Перевантаження інформацією також притаманне менеджерам, для яких фільтрування інформації, стає ключовою навичкою при прийнятті стратегічних рішень. Варто додати, що нові IT-рішення $є$ дорогими, але вони дуже швидко дешевшають, коли стають загальнодоступними.

Інформаційна підтримка стратегічного вибору пов'язана з наявністю достатнього обсягу інформації, яка необхідна для прогнозування діяльності підприємства в майбутньому. Однак неможливо надати всю необхідну інформацію в повному обсязі. Ідентифікація та прогнозування майбутніх змін, включаючи виявлення можливостей та загроз, які можуть виникнути під час співпраці із замовниками, постачальниками i конкурентами, а також можливості розвитку підприємства обмежені. Досить часто визначають так звані слабкі сигнали, що ілюструють реальність, яка тільки зароджується, але вже впливає на діяльність підприємства. Це доводить необхідність мати інформацію, яка дозволить передбачити майбутній стан підприємства та його оточення . Стратеги повинні бути забезпечені інформаційними системами, орієнтованими на сприйняття та інтерпретацію таких сигналів. Це інформаційна основа процесу стратегічного вибору. Отримуючи інформацію, що зменшує невизначеність, менеджер має можливість приймати більш раціональні рішення.

Висновки. Підприємства можуть і повинні готуватися до майбутнього. Швидкі зміни, що відбулися в останнє десятиліття, стрімкий розвиток технологій, гіперконкуренція, підвищення рівня новизни, глобалізаційні процесів, спонукають їх зосередитись на тому, що буде в майбутньому. 3 іншого боку, відсутність підготовки може знизити якість виявлення, пояснення та створення умов і, як наслідок, обмеження можливостей розвитку підприємства.

В рамках предмету дослідження інтерес представляють системи, призначені безпосередньо для стратегічного управління. Це інформаційні системи управління, направлені на підтримку діяльності в довгостроковій перспективі, шляхом залучення внутрішніх ресурсів бізнес-одиниці та ії оточення. Серед них можна виділити класи ITсистем, що забезпечують кожен етап та функцію управлінського процесу з метою здійснення стратегічного вибору. Це IT-системи класу ERP, оснащені сучасними інформаційно-комунікаційними технологіями, зокрема, Big Data, Internet of Things, Cloud Computing, e-commerce, in-memory processing . 


\section{Список бібліографічного опису:}

1.Bytniewski, A. i Hernes, M. (2017). Technologie informacyjne jako czynnik rozwoju nowych funkcjonalności zintegrowanych systemów zarządzania w ramach koncepcji big management. Studia Ekonomiczne Uniwersytetu Ekonomicznego w Katowicach. 2017. P.54-70.

2.Дятлов С.В. Система інформаційного забезпечення у сфері зовнішньоекономічної діяльності: наукові погляди щодо формування та розвитку. Економіка та держава. 2018. № 1 (100). С. 99-105.

3. Olszak, C. (2015). Komputerowe wspomaganie twórczości organizacyjnej - wybrane problemy. Studia Ekono-miczne, Zeszyty Naukowego Uniwersytetu Ekonomicznego w Katowicach, 212, 110-123.

4. Bojar, W., Rostek, K. i Knopik, L. Systemy wspomagania decyzji. Warszawa: Polskie Wydawnictwo Ekonomiczne. 2014. 5. Sopińska, A. Orientacja strategiczna przedsiębiorstw z sektora MSP w świetle badań. Organizacja i Kierowanie. 2014. 1A.P. 217-228.

6. Turban, E., Volonino, L. i Wood, G. Information Technology for Management - Advancing Sustainable, Profitable Business Growth (9th Edition). USA: John Wiley \& Sons.2013.

7. Verbeke, A. i Tung, V. The Future of Stakeholder Management Theory: A Temporal Perspective, Journal of Busines Ethics.2013. 112. 529-543. doi: 10.1007/s10551-012-1276-8.

8. Kenworthy, T. P. i Verbeke, A. The future of strategic management research: Assessing the quality of theory borrowing. European Management Journal, 2015. 33(3).P. 179-190. doi: 10.1016/j.emj.2015.03.007.

9. Porter Michael E. Millar Victor A. How Information Gives You Competitive Advantage. Harvard Business Review. JulyAugust. 1985. P. 149-152.

10.McAfee A. Brynjolfsson E. Biznesowy wymiar sztucznej inteligencji. Harvard Business Review Polska.2017. P.178-179.

\section{References:}

1.Bytniewski, A. i Hernes, M. (2017). Technologie informacyjne jako czynnik rozwoju nowych funkcjonalności zintegrowanych systemów zarządzania w ramach koncepcji big management. Studia Ekonomiczne Uniwersytetu Ekonomicznego w Katowicach. P.54-70.

2. Diatlov Ye.V. Systema informatsiinoho zabezpechennia u sferi zovnishnoekonomichnoi diialnosti: naukovi pohliady shchodo formuvannia ta rozvytku. [The system of information support in the field of foreign economic activity: scientific views on the formation and development.] Ekonomika ta derzhava. 2018. № 1 (100). P. 99-105.

3.Olszak, C. (2015). Komputerowe wspomaganie twórczości organizacyjnej - wybrane problemy. Studia Ekono-miczne, Zeszyty Naukowego Uniwersytetu Ekonomicznego w Katowicach. 212.P. 110-123.

4. Bojar, W., Rostek, K. i Knopik, L. (2014). Systemy wspomagania decyzji. Warszawa: Polskie Wydawnictwo Ekonomiczne. 5. Sopińska, A. (2014). Orientacja strategiczna przedsiębiorstw z sektora MSP w świetle badań. Organizacja i Kierowanie, 1A.P. 217-228.

6. Turban, E., Volonino, L. i Wood, G. (2013). Information Technology for Management - Advancing Sustainable, Profitable Business Growth (9th Edition). USA: John Wiley \& Sons.

7. Verbeke, A. i Tung, V. (2013). The Future of Stakeholder Management Theory: A Temporal Perspective, Journal of Busines Ethics, 112, 529-543. doi: 10.1007/s10551-012-1276-8.

8. Kenworthy, T. P. i Verbeke, A. (2015). The future of strategic management research: Assessing the quality of theory borrowing. European Management Journal, 33(3), 179-190. doi: 10.1016/j.emj.2015.03.007.

9. Porter Michael E. Millar Victor A. (1985). How Information Gives You Competitive Advantage. Harvard Business Review. July- August. P. 149-152.

10. 11.McAfee, A. i Brynjolfsson, E. (2017). Biznesowy wymiar sztucznej inteligencji. Harvard Business Review Polska. P.178-179.

Дата подання публікації 18.12.2020 p. 